\title{
Galyna Zelenko
}

\section{External Factors in Political Transition in Eastern Europe: Democratization Through Convergence}

\section{Introduction}

The ways post-communist countries develop are fundamentally different. The democratic transition that began in these countries almost simultaneously resulted in the formation of various political regimes in the post-communist space after more than 25 years of transformation - from consolidated democracies in Central and Eastern Europe and the Baltics, to openly autocratic political regimes in Asian republics, Belarus and Russia. Therefore, scientists are discussing differentiation of three groups of post-communist countries with specific politicalregimes.

Three clearly-cut clusters and two zones:

1) Inclusive: It consists of 12 countries; 11 Central European EU members and Georgia. It is interesting to note that Bulgaria, Croatia and Romania acceded to this group in 2000 and Georgia in 2015. They all adhere to grand internationalstrategy.

2) In-between., neither fully inclusive nor fully extractive. It includes four Balkan EU- candidate countries and three former Soviet republics - Armenia, Moldova and Ukraine. Balkan countries' movement - except for $\mathrm{BiH}$ - towards inclusive institutions in 2000-15 was very impressive. Except for Armenia, which joined the Eurasian Economic Union in 2015, they all tend to pursue international strategy with varying degrees ofstrength.

3) Extractive: The third group consists of Azerbaijan, Tajikistan and Turkmenistan and four of five members of Russian-dominated Eurasian Economic Union (officially EAEU) that is, Belarus, Kazakhstan, Russian Federation, and Kyrgyz Republic. Armenia, with a value of SAG of 47 in 2015, was well above the EAEU average of 33 . The difference for SAP was smaller - 36 versus 30 for theEAEU. 
Authors named these countries as Stable peace: EU plus groups 1 and 2 and Confrontation peace: Russian Federation vis-à-vis EU, NATO, Ukraine andGeorgia ${ }^{1}$.

The authors of this study believe that it is the "distance to Brussels" that determines the level of democracy development in post-communist countries. The researchers divide them into "included", "intermediate" and "excluded" and explain their openness by the specifics of political regimes².

In my opinion, the study should be supplemented by another variable that influences the way of democratic transition, but was not taken into account by the researchers - the "distance to Moscow." That is, the depth of integration with Brussels, on the one hand, and Moscow, on the other, determines the quality of a political regime. It concerns all post-communist countries in view of Slovakian authoritarian experience at the time of Vladimir Mečiar or Ukraine at the time of President Viktor Yanukovych. All this gives grounds for the hypothesis that convergence can both stimulate democratization processes and cause their regression. So, my research sought to addresses three important questions:

1. What were political economy similarities and differences, i.e., domestic grand strategies, in trajectories of East-Europe countries as post-communist countries? How far did they move, if at all, towards consolidateddemocracies?

2. What impact did external factors in theirpolitics? Mechanisms of convergence

East-Central Europe countries andEU. The specific of convergence in some post-sovietcountries.

3. Why convergence processes are so important for democratic transition post-communist countries of East Europe? What factors explain patterns and differences? Do they corroborate the persistence of European civilizationcleavage?

The framework combines concepts borrowed from Acemonglu's and Robinson's (The Origins of Power, Prosperity and Poverty, 2012) and W. Morawski and A. Kaminsky (Institutional and regional outcomes of transformation / Facing Future Challenges, 2016), Freedom House Score of democracy and the score of National Council of Reform (Ukraine).

\section{Theoretical substantiation of convergence processes}

The theory of convergence (from Lat. Convergere - to incline together) is based on the idea of predominant tendencies to the integration of elements into a system over the processes of differentiation, distinction and individualization. Like most social theories, it was borrowed from biology and developed by socio-political sciences. As a scientific concept, the idea of convergence is developed in the works of P. Burnell ${ }^{3}$, D. Brinks

\footnotetext{
Wobec wyzwań jutra, ed. W. Morawski, Warsaw: Wolter Kluver, 2016; T.G. Grosse, Changes in EU common market in the aftermath of crises, „Studia Polityczne” 2018, Vol. 46, No. 3, pp. 87-115.

2 T. G. Grosse, Changes in EU common market in the aftermath of crises, „Studia Polityczne” 2018, Vol. 46, No. 3, p. 89.

3 P.J. Burnell, International Democracy Promotion: A Role for Public Goods Theory? „Contemporary Politics", 2008, Vol. 14, No. 1, p. 37-52.
} 
and M. Coppedge 4 , S. Hantington 5 , H. Hale, V. Helman 7 , K. Gleditch and M. Ward 8 , A. Moravcsik ${ }^{9}$, G. Pridham and T. Vanhanen ${ }^{10}$, N. Rozov ${ }^{11}$, T. Smith ${ }^{12}$, L. Whitehead ${ }^{13}$ and others. They all consider convergence as maximum co-operation of economically less developed countries with more developed ones in order to balance potentials, resources, and institutional systems. Interestingly, scientists have long thought that convergence is capable of stimulating the socio- economic development of less developed countries, but unsuitable for stimulating the development of political systems, because countries must "mature" for democracy. However, the CEE countries (and this is a unique case) were able to, within a short period of time, by convergence with the EU and NATO, not only destroy the authoritarian regime, but also join the category of "stable democracies."

It should be emphasized that international influence is manifested not so much by the "links" of non-democratic regimes with developed democracies (through trade, migration, communication, educational and scientific exchanges), but through a successful use of "leverages" - purposeful influence on these regimes (international assistance, membership in international organizations $)^{14}$. Therefore, gradual convergence of the CEE countries with the EU and membership in the Association in 2004, the program of enhanced cooperation with the IMF and the World Bank, the program of military cooperation with NATO and joining this organization were targeted instruments that, despite numerous obstacles and inertia of the political systems, stimulated democratic transit processes in the countries of Central and Eastern Europe.

4 D.Brinks, M. Coppedge, Diffusion is No Illusion: Neighbor Emulation in the Third Wave of Democracy, „Comparative Political Studies", 2006, Vol. 39, p. 463-489.

5 S. P. Hantington. After Twenty Years: The Future of the Third Wave, „Journal of Democracy”,1997, Vol. 8, No. 4, p. 3-12.

6 H. E. Hale, Patronal Democracy. Eurasian Regime Dynamics in Comparative Perspective, Cambridge 2015, pp. 530.

7 В. Гельман, «Подрывные» институты и неформальное управление в современной России, „Полития", 2010, №2, с. 6-24.

8 K.S.Gleditsch, Ward M.D. Diffusion and the Intarnational Context of Democratization, „International Organization", 2006,Vol. 60, p. 911-933.

9 A. Moravcsik, Introduction: Integration International and Domestic Theories of International Bargaining, [in:] Double-Edged Doplomacy: International Bargaining and Domestic Politics, ed. by P.B. Evans, H.K. Jacobson, R.D. Putnam, Barleley (CA): University of California Press1993,p. 5-9.

10 Democratization in Eastern Europe: Domestic and International Perspectives, ed. G. Pridham, T. Vanhanen New York: Routledge 1994.

11 Н.С. Розов, Неопатримониальные режимы: разнообразие, динамика и перспективы демократизащии, „Полис. Политическиеисследования”, 2016, №1, с. 139-140.

12 T. Smith, America's Mission. The United States and the World Worldwide Straggle for Democracy in the Twentieth Century, Princeton (NJ): Prinston University Press 1994, pp. 309.

13 L. Whitehead, Democracy by Convergence and Southern Europe: A Comparative Politics Perspective, [in:] Encouraging Democracy: The Intarnational Context of Regime Transition in Southern Europe, ed. By G. Pridham, New York: St. Martin's Press1991, p. 1-29; L. Whitehead, Democratisation: Theory and Experience, Oxford: Oxford University Press 2002.

14 L. Whitehead, Democratisation: Theory and Experience, Oxford: Oxford University Press 2002. 
However, one should pay attention to the nature of exogenous influences in the CEE post-communist countries. They are located between two centers of power - big geopolitical players - the EU and Russia. At first glance, it is a standard situation. Yet, these geopolitical players have fundamentally different political regimes: consolidated EU democracies and an increasingly pronounced autocratic regime in Russia. Such a combination of geopolitical influences affects the nature of political transit in the CEE post-communist countries.

It is of interest that Russia, which is one of post-communist countries, also began democratic transition in the early 1990's. However, over time, weak preconditions for democratization caused a regression to an authoritarian political regime, albeit a hybrid one. All post-Soviet republics, except the Baltic States, faced deceleration of democratization processes. It is clear that effective democratic transit is conditioned, primarily, by internal prerequisites - the level of political consciousness and political will, a critical mass of reformers and their political will to democratize. However, deep integration of former Soviet republics' economies significantly limited the possibilities for foreign policy maneuver and left a fairly limited choice for post-Soviet republics remaining in the sphere of Russia's influence. It should also be taken into account that "democracy promotion" can be successful when it is a supplement rather than a substitute for domestic political processes. And post-Soviet countries did not have enough internal preconditions for democratization.

To confirm this statement, here is a table showing the state of democracy in some post- communist countries - those who show the best and worst results (Tab. 1).

Table 1. Democracy in some post-communist countries $(2018)^{15}$

\begin{tabular}{|c|c|c|c|c|c|c|c|c|}
\hline & 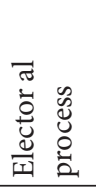 & 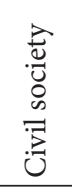 & 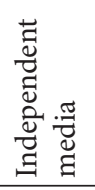 & 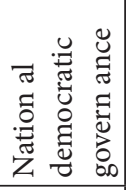 & 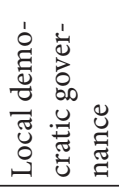 & 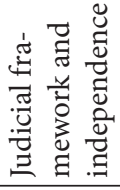 & 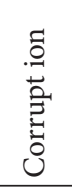 & 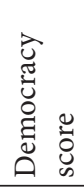 \\
\hline Ukraine & 3,50 & 2,25 & 4,00 & 5,75 & 5,25 & 6,00 & 6,00 & 4,64 \\
\hline Georgia & 4,50 & 3,75 & 4,00 & 5,50 & 5,50 & 4,75 & 4,50 & 4,68 \\
\hline Russia & 6,75 & 6,50 & 6,50 & 6,75 & 6,26 & 6,50 & 6,75 & 6,61 \\
\hline Kazakhstan & 6,75 & 6,50 & 6,75 & 6,75 & 6,50 & 6,50 & 6,75 & 6,71 \\
\hline Hungary & 2,75 & 2,50 & 3,75 & 4,00 & 3,00 & 3,00 & 4,00 & 3,71 \\
\hline Slovak & 1,50 & 1,75 & 3,00 & 3,00 & 2,50 & 2,75 & 3,75 & 2,61 \\
\hline Poland & 1,50 & 1,50 & 2,75 & 2,75 & 1,50 & 2,75 & 3,50 & 2,89 \\
\hline Czech Republic & 1,25 & 1,75 & 2,75 & 2,75 & 1,75 & 1,75 & 3,50 & 2,29 \\
\hline
\end{tabular}

As can be seen from the table, countries that have fallen into the "collective west" sphere of influence show the best results of democratization processes. This gives

15 The table is compiled by the author based on «Freedom in the world 2018» // URL: https://freedomhouse.org/report/nations-transit/nations-transit-2018. 
grounds for asserting the possibility to stimulate development of the institutional system of democracy, provided that it is properly perceived by both society and elites.

Socio-political processes in post-Soviet countries give reason to assert that convergence processes can both stimulate democratic transit, and cause the curtailment of democratization processes. It is important what country undergoes convergence. If the countries are democratic, integration is a progress (as in the EU case). If a country that influences smaller countries is undemocratic, democratization processes in these countries are usually stagnant (as in the case of Russia and the Commonwealth of Independent States).

\section{Mechanisms of convergence}

The European Union is considered to be one of the most successful integration projects in the world. Its advantages are that integration, which began on the European continent in the second half of the twentieth century in the economic sphere in order to counter US expansion into European markets, eventually turned into a political process, an association based on universal human values. Accession to the EU envisages a certain level of development of political, economic and social systems. Meeting members hip criteria tends to bring a candidate country to a higher standard. The European integration process affects socio-cultural and politicalspheres, thus it is technically impossible to meet membership criteria without a qualitative transformation of society.

EU enlargement is unprecedented as its membership was gained by countries that for a long time belonged to a different type of political regime. The fact that these countries met the membership criteria and acquired a lot of characteristics of Western democracies indicates the possibility of applying institutional mechanisms that gave an opportunity to stimulate democratization processes.

It should be noted that political science views this process differently, but now (given the development of post-Soviet countries), most researchers agree that the "collective West" factor has become a protector from the formation of clan-oligarchic political regimes. "In CEE countries, the European integration process and the acceptance of a number of obligations, both socio-economic and political, have created a favorable 'external democratic preference,' which is a kind of a 'stopper for the aggressive strategies of each political force' and is a factor influencing changes of institutional conditions" (M. Rozov) $)^{16}$. The 2000s expansion and the EU pressure turned out to be a kind of "antidote" for Eastern Europeans, which prevented them from slipping into a neo-patrimonial regime and deforming the political system (V. Gelman) ${ }^{17}$. CEE countries, which gained complete independence after the Soviet Union collapsed, saw

16 Н.С. Розов, Неопатримониальные режимы: разнообразие, динамика и перспективы демократизации, „Полис. Политические исследования”, 2016, № 1, с. 139-140.

17 В. Гельман, Politics versus policy: технократические ловушки постсоветских преобразований, СПб.: Издательство Европейского университета в Санкт-Петербурге 2017, сс. 38. 
the opportunity to join the Western clubs as an incredibly effective counterbalance to the pressure of the longtime Soviet / Russian hegemon (T. Collton and S. Charap) ${ }^{18}$.

However, when CEE countries began a rapprochement with the EU on its terms, they faced a dilemma - to delegate their own sovereignty or transit independently with a not very clear and guaranteed result? It is hard to deny that external lending and extremely high financial and political dependence on partner countries and, as a result, curtailed political sovereignty, are not the best conditions for the state functioning. But for post-communist countries, this is a plus rather than a minus. We should take into account a possible alternative. And if there is no "collective West" factor - the alternative could be formation of hybrid regimes (as in post-Soviet countries) with all threats and risks for the region as a whole. Of course, "external democratic preferences" in the collective West form do not guarantee rapid democratization. The country itself decides on the way to convert the "collective West" role, but these influences create essential conditions under which undemocratic regimes are forced to transform.

Yet, the enlargement of the EU should not be seen as unilateral imposition or expansion of Western standards and procedures on post-communist countries. The EU and NATO enlargement is rather a process of convergence, involving certain institutional and socio-cultural changes within the countries that represent the integration core. Without such changes, the member countries influence the applicant countries only externally. In this sense, it is no good to simplify the problem, considering thisprocess only as a one-sided influence on the applicant countries. Of course, the EU enlargement would not be possible without a fundamental EU reform. The ongoing process of reforms, which began with the signing of the Treaty on European Union in 1992, prepared the EU for the enlargement to the East. The Reform Treaty concerned not only enlargement, it also provided for the revision of European institutions, which was necessary for the EU smooth enlargement.

The EU influence on social and political transits in CEE countries involved creation of a comprehensive program of reforms and resource support in implementing them, i.e., support for the strategy of integration of new members aimed primarily at creating a legal infrastructure for the integration process. The following measures ensured the evolutionary development of the process:

- Creation of a free trade area and economic cooperation institutes under the PHARE program specifically focused on providing financial assistance and economic expert analyses, as well as attracting investments for implementing economic reforms. Later on, this program became the main financial instrument for implementing the EU eastward enlargement strategy. In the early 1990 's, the program budget was about 1 billion ECU a year. Already in 1992, the EU countries accounted for almost half of the CEE countries' exports whilst the exports of the former Comecon countries decreased down to onefifth;

18 Т. Колтон, С. Чарап, Украинский кризис: Победителей нет,„Россия в глобальной политике”, Спецвыпуск, 2017, Декабрь, с. 46-47. 
- Political dialogue between the EU and potential candidate countries, definition of membership criteria (known as Copenhagen criteria) and their implementation. To meet these criteria, the candidate countries had to achieve stability of political institutions guaranteeing democracy, the rule of law, transparent and democratic elections, independent media, human rights and freedoms, respect for and protection ofminorities;

- Harmonization of internal market legislation (as outlined in the White Paper in 1995); Development of National Pre-Accession Programs in order to implement the Partnership Programs during the accession to the Union;

- Development of bilateral and multilateral cooperation in the cultural sphere under the PHARE program through cooperation between non-governmental organizations, which stimulated the public sectordevelopment;

- Creation of necessary conditions for candidate countries' integration through institutional reforms in order to bring their laws into line with the body of European law and to ensure their effective application by appropriate administrative and judicialauthorities;

- Creation of a system of management, training and retraining of civil servants and private sector employees, implementation of modern methods of public administration under the Twinning program.

Integration in the "European Administrative Space" envisaged the development of the legislative framework (adoption of laws on civil service and other acts laying the foundation of the activities of public administration bodies); administrative restructuring that results in the formation and convergence of state institutional structures; development of human resources through an effective regional policy aimed at economic convergence of the regions; creation of an effective accountability system focused on the internal and external financial supervision system. Besides, the applicant countries had to conduct regionalization, because the tools, organization and financing of the EU regional policy envisaged updating of regional division and territorial division system so that regional policy could be implemented in the best way, without which human resources cannot develop.

There were radical changes in the structure of mass consciousness in CEE countries influenced by measures subordinated to the goal of integration. In particular, election processes acquired the traits of competition typical of political parties' programs rather than values. With the beginning of democratic transformations, CEE countries confirmed their course for ensuring human rights for all their citizens by appropriate regulations. Having ratified the European Convention on Human Rights, they joined the Framework Convention for the Protection of National Minorities, the European Charter of Local Self-Government, the International Covenant on Civil and Political Rights, the International Covenant on Economic, Social and Cultural Rights, the International Convention on the Elimination of All Forms of Discrimination against Women, the Convention on the Rights of the Child, etc. That confirmed their desire to implement European human rights standards in the national legislations of CEEcountries. 
Thus, integration of CEE countries in the EU became an important disciplinary factor, especially for the governments of these countries. They elaborated detailed programs to meet the membership criteria and implemented detailed institutional tools, which made it impossible to form hybrid political regimes in these countries. It was because of these tools that the "EU factor" served as a catalyst for establishing democratic institutions.

\section{Convergence in Ukraine}

Hybrid political regimes were formed in the post-Soviet countries that remained in the sphere of Russia's influence (H. Hale, V. Helman, A. Fisun $\left.{ }^{19}\right)$. Moreover, this process took place simultaneously with similar processes in Russia. It became very expensive to leave the Russian influence sphere. This explains the armed conflicts in Georgia and Ukraine, where Russian aggression is disguised as allegedly civilconflicts.

Neo-patrimonialism is typical of most post-Soviet countries where democratic political institutions became a facade whilst societies live on the basis of informal institutions which are often quite opposite to the official ones. This accounts for absolutely hopeless, in terms of the future, inconsistent, unstable and unpredictable political regimes.

In the post-Soviet space, we are witnessing attempts to destroy the hybrid regimes and leave the sphere of Russia's influence. A good example is Georgia, Moldova and Ukraine. By signing EU association agreements, these countries received the necessary "external institutional preferences" for democratization through convergence. Referring to Freedom House democratization indexes, we can see that democratization dynamics in these countries improved after signing the EU association agreements. For these countries, the external stimuli to democratization certainly became possible after creating the necessary internal conditions for democratization.

Reference can be made to the Freedom House democracy dynamics in Ukraine in this regard (Tab. 2).

Democratization through convergence in Ukraine is a special case. After the Revolution of Dignity in 2014 when pro-European political forces come to power, a broad coalition was formed in the parliament. This made it possible to conduct intensive reforms during the first post-revolutionary year. However, after the broad coalition collapsed in autumn 2015, external players - the EU, international financial institutions (the IMF and the World Bank) - became the main actors of the reforms.

The impact of exogenous factors is clearly demonstrated in the diagram below. It shows the dynamics of the reforms conducted by the National Council of Reforms of Ukraine from 2015 (Tab. 3).

19 O. Fisun, The Future of Ukraine's Neopatrimonial Democracy, „PONARS Eurasia”, 2015, October, No. 394, p. 2. 
Pobrane z czasopisma Wschód Europy http://journals.umcs.pl/we

Data: 26/04/2023 16:47:28

External Factors in Political Transition in Eastern Europe: Democratization Through Convergence

Table 2. Nations in Transit Ratings and Averaged Scores ${ }^{20}$

\begin{tabular}{|l|c|c|c|c|c|c|c|c|c|c|}
\hline & 2009 & 2010 & 2011 & 2012 & 2013 & 2014 & 2015 & 2016 & 2017 & 2018 \\
\hline $\begin{array}{l}\text { National Democratic } \\
\text { Governance }\end{array}$ & 5,00 & 5,00 & 5,50 & 5,75 & 5,75 & 6,00 & 6,00 & 5,75 & 5,75 & 5,75 \\
\hline Electoral Process & 3,50 & 3,50 & 3,50 & 3,75 & 4,00 & 4,00 & 3,50 & 3,50 & 3,50 & 3,50 \\
\hline Civil Society & 2,75 & 2,75 & 2,75 & 2,75 & 2,75 & 2,50 & 2,25 & 2,25 & 2,50 & 2,75 \\
\hline Independent Media & 3,50 & 3,50 & 3,75 & 4,00 & 4,00 & 4,25 & 4,00 & 4,00 & 4,00 & 4,25 \\
\hline $\begin{array}{l}\text { Local Democratic } \\
\text { Governance }\end{array}$ & 5,25 & 5,25 & 5,50 & 5,50 & 5,50 & 5,50 & 5,50 & 5,25 & 5,00 & 4,75 \\
\hline $\begin{array}{l}\text { Judicial Framework and } \\
\text { Independence }\end{array}$ & 5,00 & 5,00 & 5,50 & 6,00 & 6,00 & 6,00 & 6,00 & 6,00 & 5,75 & 5,75 \\
\hline Corruption & 5,75 & 5,75 & 5,75 & 6,00 & 6,00 & 6,25 & 6,00 & 6,00 & 5,75 & 5,75 \\
\hline Democracy Score & 4,39 & 4,39 & 4,61 & 4,82 & 4,86 & 4,93 & 4,75 & 4,68 & 4,61 & 4,64 \\
\hline
\end{tabular}

Table 3. Reforms dynamics in Ukraine since $2015^{21}$

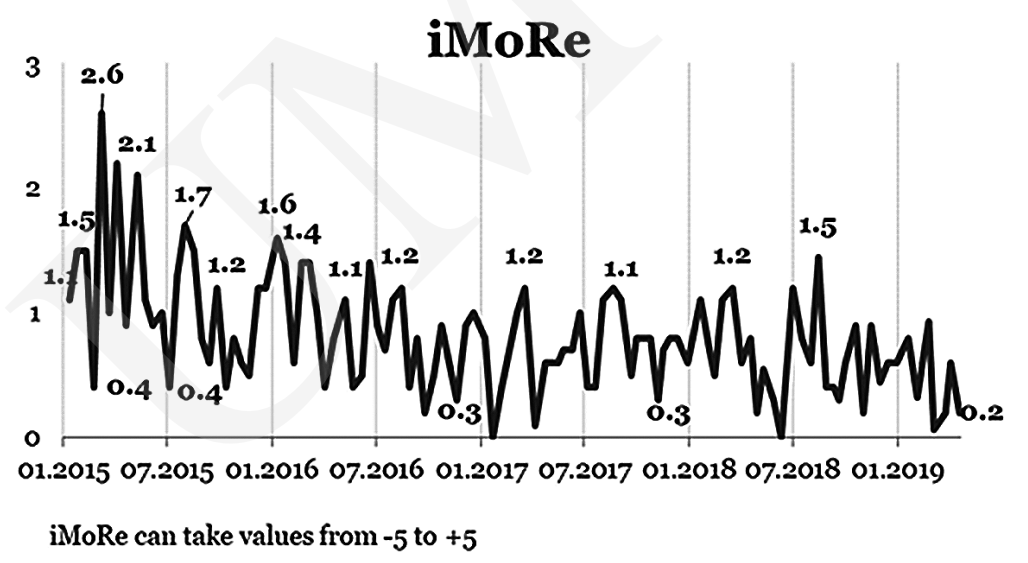

20 Nations in Transit Ratings and Averaged Scores// URL. https://freedomhouse.org/report/nations-transit/2018/ukraineThe ratings are based on a scale of 1 to 7 , with 1 representing the highest level of democratic progress and 7 the lowest. The Democracy Score is an average of ratings for the categories tracked in a given year

21 IMoRe dynamics in Ukraine // URL. http://imorevox.org/imore-in-charts/ For the purposes of this index, a reform (anti- reform) is considered to be a normative act which changes the behavior of economic agents and results in more (less) efficient use of resources. The evaluation period is equal to two weeks (except holiday-heavy periods such as around New Year's and Christmas). Reforms and anti-reforms are chosen by the iMoRe project manager and two editors from the iMoRe Editorial Board. They use the news feed supplied by the news agency Interfax-Ukraine, iMoRe's main media partner, as well as information from the official internet pages of the Verkhovna Rada (Parliament), President of Ukraine, Cabinet of Ministers, National Bank and other governmental institutions. Normative acts chosen for evaluation are then assigned to the Index components and their respective focus areas (directions). 
Monitoring is based on the laws and regulations adopted by the parliament and government. As can be seen from the diagram, Ukrainian reforms are cyclical. The diagram shows that after the broad coalition collapsed and a situational coalition was formed, the reforms continued, albeit lessintensively. This slowdown in the reforms resulted from the fact that despite early elections, the parliament was formed on the basis of the old electoral system created during the presidency of Yanukovych as a guarantee for financial-industrial groups (known as oligarchs) to be able to regain power. Because of this, the reformers received a minority status in the parliament. Such international financial institutions as the IMF and the World Bank became the main drivers of the reforms, first of all because they are the largest financial donors to the Ukrainian economy. Since the country was on the brink of default, MPs who primarily represented oligarchs' interests in the parliament were forced, albeit very reluctantly, to support the reforms that were a prerequisite for obtaining the IMF macro-financial assistance. Indeed, the termination of lending would mean a financial collapse in the country and a loss of power. This fear is also aggravated by the Russian military aggression in Donbas and by the fear of being left to fend for oneself in this conflict. However, it is wrong to say that reforms are conducted solely under pressure from the international financial institutions. Although many laws are adopted within the framework of the EU Association Agreement, high-profile reforms are required by international financial institutions. Among them are the judicial reform, electronic declaration of officials, anti-corruption legislation and creation of anti-corruption bodies. The European Union has played an important role in stimulating reforms in Ukraine. Thus, during the negotiations on the provision of visa-free regime to Ukraine, about 140 laws and regulations (known as visa-free package of laws) aimed at institutional improvement of socio-political processes wereadopted.

\section{Conclusions}

- According to the dynamics of democratic transit in post-communist countries, it seems reasonable to assert that both democratization through convergence and regress of democratization through convergence arepossible.

- The results of these processes depend on what entity the states are integrated in. As to the number of post-Soviet countries, Russia had a toxic effect on the processes of democratization. The total penetration of Russian business and the financing of pro-Russian political forces in the parliament, as well as the policy of expansion, which manifested itself in all spheres, made it possible to form a pro-Russian policy. However, this led to the conservation of inefficient hybridregimes.

- The model of political transition in East Europe post-communist countries has exogenous and endogenous features. Political changes have grown not so much from internal development, but as a result of communicative strategies of the collective West. The role of communicative strategies was to "bring up" these countries to a higher state ofdevelopment. 
- The convergence of post-communist CEE countries with the EU created institutional preferences for democratic transit, despite present problems in these countries. A clear institutional policy in CEE countries precluded the formation of monopolies in the economy with the subsequent merging of politics and business. That is why these countries avoided significant deformations of democratic institutions and the establishment of hybrid political regimes, as was the case in most post-Soviet republics.

- The case of Ukraine is an additional indication of the decisive importance of the influence of exogenous factors in democratic transit. Its value is amplified at the end of the electoral cycle, when internal factors have weakened considerably due to a number of reasons and the situation is "the worse it is the better".

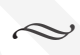

\begin{abstract}
The ways post-communist countries develop are fundamentally different. The democratic transition that began in these countries almost simultaneously resulted in the formation of various political regimes in the post-communist space after more than 25 years of transformation - from consolidated democracies in Central and Eastern Europe and the Baltics, to openly autocratic political regimes in Asian republics, Belarus and Russia. Some authors believe that it is the "distance to Brussels" that determines the level of democracy development in post-communist countries. But the "distance to Moscow" determines political transition too. That is, the depth of integration with Brussels, on the one hand, and Moscow, on the other, determines the quality of a political regime.

All this gives grounds for the hypothesis that convergence can both stimulate democratization processes and cause their regression. So, my research sought to addresses such questions: What impact did external factors in their politics? Why convergence processes are so important for democratic transition post-communist countries of East Europe? What factors explain patterns and differences? The author pays attention to the nature of exogenous influences in the East Europe countries, which are located between two centers of power - big geopolitical players - the EU and Russia. Also, author analyzes the impact of convergence process on political transition in Ukraine as very specific case of political transition.
\end{abstract}

Keywords: democratization, convergence, external factors, political transition, Eastern Europe

\title{
Wpływ czynników zewnętrznych na tranzyt polityczny krajów Europy Wschodniej: demokratyzacja przez konwergencje
}

Streszczenie: Trajektorie rozwoju krajów postkomunistycznych są zasadniczo różne. Demokratyczny okres przejściowy, który rozpoczął się niemal równocześnie, po ponad 25 latach transformacji w przestrzeni postkomunistycznej doprowadził do sformowania różnych systemów politycznych - od skonsolidowanych demokracji w Europie Środkowej i Wschodniej i krajach bałtyckich po wyraźnie autorytarne reżimy polityczne w azjatyckich republikach, na Białorusi i w Rosji. Niektórzy autorzy uważa- 
ją, że to właśnie „odległość od Brukseli” definiuje poziom rozwoju demokracji w krajach postkomunistycznych. Zdaniem autora "odległość od Moskwy” także określa jakość tranzytu politycznego. Innymi słowy, głębokość integracji z Brukselą z jednej strony oraz z Moskwą z drugiej - w sposób zasadniczy determinuje jakość reżimu politycznego. Wszystko to stanowi podstawę do hipotezy, że konwergencja może zarówno stymulować procesy demokratyzacji, jak i powodować ich regresję. Dlatego moje badania skupiały się na takich pytaniach: w jaki sposób czynniki zewnętrzne wpłynęły na politykę poszczególnych państw?; dlaczego procesy konwergencji są tak ważne dla demokratycznych postkomunistycznych krajów Europy Wschodniej podczas okresu przejściowego?; jakie czynniki wyjaśniają wzory i różnice? Autor zwrócił uwagę na naturę wpływów egzogenicznych w krajach Europy Wschodniej, położonych pomiędzy dwoma centrum siły, głównymi graczami geopolitycznymi - UE a Rosją. Autor podjął się również analizy wpływu procesu konwergencji na przemiany polityczne w Ukrainie jako bardzo specyficzny przypadek transformacji politycznej.

Słowa kluczowe: demokratyzacja, konwergencja, czynniki zewnętrzne, tranzyt polityczny, Europa Wschodnia

\section{Влияние внешних факторов на политический транзит стран Восточной Европы: демократизация посредством конвергенции}

Аннотация: Траектории развития посткоммунистических стран принципиально различные. Демократический переход, начавшийся почти одновременно, привел к формированию различных политических режимов на посткоммунистическом пространстве после более чем 25-летней трансформации - от консолидированных демократий в Центральной и Восточной Европе и странах Балтии до явно авторитарных политических режимов в Азиатских республиках, Беларуси и России. Некоторые авторы считают, что именно «расстояние до Брюсселя» определяет уровень развития демократии в посткоммунистических странах. Но «расстояние до Москвы», по мнению автора, также определяет качество политического транзита. То есть глубина интеграции с Брюсселем, с одной стороны, и Москвой, с другой, существенно определяет качество политического режима.

Все это дает основания для гипотезы о том, что конвергенция может как стимулировать процессы демократизации, так и вызывать их регресс. Итак, мое исследование было направлено на такие вопросы: какое влияние оказали внешние факторы на их политику? Почему процессы конвергенции так важны для демократических переходных посткоммунистических стран Восточной Европы? Какие факторы объясняют закономерности и различия?

Автор обращает внимание на природу экзогенных влияний в странах Восточной Европы, которые расположены между двумя центрами силы - крупными геополитическими игроками - ЕС и Россией. Также автор анализирует влияние процесса конвергенции на политический переход в Украине как очень специфический случай политического перехода.

Ключевые слова: демократизация, конвергенция, внешние факторы, политический транзит, Восточная Европа 
Pobrane z czasopisma Wschód Europy http://journals.umcs.pl/we

Data: 26/04/2023 16:47:28

External Factors in Political Transition in Eastern Europe: Democratization Through Convergence

\section{Bibliography}

Brinks D., Coppedge M., Doffusion is No Illusion: Neighbor Emulation in the Third Wave of Democracy, "Comparative Political Studies", 2006, Vol. 39, p. 463-489.

DOl: https://doi.org/10.1177/0010414005276666.

Burnell P.J., International Democracy Promotion: A Role for Public Goods Theory? „Contemporary Politics", 2008, Vol. 14, No. 1, p. 37-52. DOl: https://doi.org/10.1080/13569770801913249.

Democratization in Eastern Europe: Domestic and International Perspectives, ed. G. Pridham, T. Vanhanen New York: Routledge 1994.

Fisun 0., The Future of Ukraine's Neopatrimonial Democracy, „PONARS Eurasia”, 2015, October, No. 394. Freedom in the world 2018 // URL: https://freedomhouse.org/report/nations-transit/nations-transit-2018.

Gleditsch K.S., Ward M.D., Diffusion and the Intarnational Context of Democratization, "International Organization", 2006, Vol. 60, p. 911-933. D0l: https://doi.org/10.1017/S0020818306060309.

GrosseT. G., Changes in EU common market in the aftermath of crises, "Studia Polityczne”, 2018, Vol. 46, No. 3, pp. 87-115.

Hale H., Patronal Democracy. 2015. - 530 p.

Hantington S.P., After Twenty Years: The Future of the Third Wave, "Journal of Democracy",1997, Vol. 8, No. 4, p. 3-12. DOl: https://doi.org/10.1353/jod.1997.0059.

IMoRe dynamics in Ukraine // URL. http://imorevox.org/imore-in-charts/

Moravcsik A., Introduction: Integration International and Domestic Theories of International Bargaining, [in:] Double-Edged Doplomacy: International Bargaining and Domestic Politics, ed. P.B. Evans, H.K. Jacobson, R.D., Berkleley (CA): University of California Press 1993, p. 5-9.

Nations in Transit Ratings and Averaged Scores// URL. https://freedomhouse.org/report/nations-transit/2018/ukraine

Smith T., America's Mission. The United States and the World Worldwide Straggle for Democracy in the Twentieth Century, Princeton (NJ): Prinston University Press 1994, pp. 309.

Whitehead L., Democracy by Convergence and Southern Europe: A Comparative Politics Perspective, [in:] Encouraging Democracy: The Intarnational Context of Regime Transition in Southern Europe, ed. By

G. Pridham, New York: St. Martin's Press 1991, p. 1-29.

Whitehead L., Democratisation: Theory and Experience, Oxford: Oxford University Press 2002.

Wobec wyzwań jutra, ed. W. Morawski, Warsaw: Wolter Kluver, 2016.

Гельман В., «Подрывные» институты и неформальное управление в современной России, „Полития", 2010, № 2, c. 6-24.

Гельман B., Politicsversuspolicy: технократические ловушки постсоветских преобразований, СПб: Издательство Европейского университета в Санкт-Петербурге 2017, сс. 38.

Колтон Т., Чарап С., Украинский кризис: Победителей нет, „Россия в глобальной политике”, Спецвыпуск, 2017, Декабрь, с. 46-47.

Розов Н.С., Неопатримониальные режимы: разнообразие, динамика и перспективы демократизации, „Полис. Политическиеисследования”, 2016, № 1, с. 139-140. 